DOI: $10.20961 / j p s c r . v 3 i 2.22534$

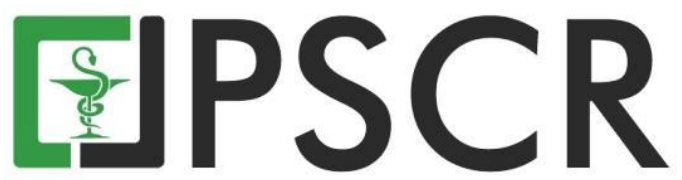

\title{
Pengaruh Gel Kombinasi Ekstrak Kulit Semangka (Citrullus lanatus (Thunb.)) dan Ekstrak Kulit Manggis (Garcinia Mangostana L.) terhadap Penyembuhan Luka Bakar pada Kelinci
}

\author{
Yosephie Vania Prima Aryati ${ }^{*}$, Iwan Setiawan ${ }^{1}$, Nofi Risa Ariani ${ }^{1}$ dan Diah Dwi Hastuti ${ }^{1}$ \\ ${ }^{1}$ Program Studi Farmasi, STIKES NASIONAL, Surakarta
}

*email korespondensi : yosephinevania998@gmail.com

\begin{abstract}
Abstrak: Luka bakar disebabkan karena kerusakan atau kehilangan jaringan akibat kontak dengan sumber panas. Pengobatan luka bakar dilakukan dengan mengembalikan fungsi dan bentuk jaringan kulit kembali. Penggunaan tanaman herbal sebagai alternatif pengobatan luka bakar meningkat karena minimnya efek samping yang ditimbulkan. Kulit semangka (Citrullus lanatus (Thunb.)) mempunyai kandungan alkaloid berupa sitrulin yang berperan dalam proses penyembuhan luka serta kulit manggis (Garcinia mangostana L.) memiliki kandungan flavonoid berupa xanton yang memiliki efek anti inflamasi dengan memicu pembentukan kolagen yang berperan penting dalam pemeliharaan struktur dan penyembuhan luka. Penelitian ini bertujuan mengetahui pengaruh gel kombinasi ekstrak kulit semangka dan kulit manggis yang memiliki efek antiinflamasi pada luka bakar yang terdapat pada punggung kelinci serta kontrol kualitas sediaan gel yang dibuat. Pengujian mutu fisik gel yang dilakukan meliputi uji organoleptik, $\mathrm{pH}$, homogenitas, viskositas, daya lekat, daya sebar, daya proteksi dan aseptabilitas pada penyimpanan hari ke-0 sampai hari ke-28. Uji aktivitas gel dilakukan pada 7 ekor kelinci yang dibagi dalam 7 kelompok perlakuan yang terdiri dari kontrol negatif, kontrol positif, kulit semangka (KS) (100), kulit manggis (KM) (100), kulit semangka-kulit manggis (KS-KM) (25:75), kulit semangka-kulit manggis (KS-KM) (50:50), kulit semangka-kulit manggis (KSKM) (75:25). Setiap kelinci dibuat luka bakar menggunakan lempeng logam panas berdiameter 2 $\mathrm{cm}$. Pengukuran diameter luka dilakukan selama 14 hari. Hasil penelitian menunjukkan bahwa gel kombinasi ekstrak kulit semangka dan kulit manggis dapat menurunkan diameter luka bakar. Formula efektif yaitu formula KSKM 75:25 dengan rata-rata diameter 1,29 cm.
\end{abstract}

Kata kunci: Luka bakar; Citrullus lanatus; Garcinia mangostana; Gel

Abstract. The Effect of Watermelon Skin Extract Gel Combination (Citrullus Lanatus (Thunb)) and Mangosteen Skin Extract (Garcinia mangostana L.) against Healing Burns in

Rabbits. Burns caused by damage or loss of tissue due to contact with heat sources. Treatment of burns is done by restoring the function and shape of skin tissue back. The use of herbal plants as an alternative treatment of burns increasing due to the lack of side effects caused. Watermelon skin (Citrullus lanatus (Thunb.)) Has an alkaloid content of sitrulin that plays a role in the healing process of wound and mangosteen skin (Garcinia mangostana L.) contains xanton flavonoids that have anti-inflammatory effect by triggering the formation of collagen which plays an important role in the maintenance of the skin structures and wound healing. The aim of this research is to know the effect of gel combination of skin watermelon extract and mangosteen skin which has anti-inflammatory effect on rabbit's back burn and quality control of gel 
preparation. Testing of physical quality of gels made include organoleptic test, $\mathrm{pH}$, homogeneity, viscosity, adhesion, dispersion, protection and acceptability at 0 days storage until the 28th day. The gel activity test was performed on 7 rabbits divided into 7 treatment groups consisting of negative control, positive control, KS (100), KM (100), KSKM (25:75), KSKM (50:50), KSKM (75: 25). Each rabbit is burned using a hot metal plate $2 \mathrm{~cm}$ in diameter. Wound diameter was measured for 14 days. The results showed that gel combination of watermelon extract and mangosteen skin can decrease burn diameter. The effective formula is the 75:25 KSKM formula with an average diameter of $1.29 \mathrm{~cm}$.

Keywords: Healing burns; Citrullus lanatus; Garcinia mangostana; Gel

\section{Pendahuluan}

Luka bakar (combustio) adalah kerusakan atau kehilangan jaringan akibat kontak dengan sumber panas seperti api, air panas, bahan kimia, listrik, dan radiasi (Moenadjat, 2009). World Health Organization (WHO) memperkirakan bahwa terdapat 265.000 kematian yang terjadi setiap tahunnya di seluruh dunia akibat luka bakar (WHO, 2014). Di Indonesia, prevalensi luka bakar pada tahun 2013 adalah sebesar $0.7 \%$ dan telah mengalami penurunan sebesar $1.5 \%$ dibandingkan pada tahun 2008 (2.2\%). Provinsi dengan prevalensi tertinggi adalah Papua (2.0\%) dan Bangka Belitung (1.4\%), sedangkan prevalensi di Jawa Timur sebesar 0.7\% (Depkes, 2013).

Prinsip pengobatan luka bakar adalah mengembalikan fungsi dan bentuk jaringan kulit kembali normal dengan komplikasi lokal seminimal mungkin. Gaya hidup back to nature menjadikan masyarakat saat menggunakan obat herbal sebagai alternatif pengobatan. Tanaman herbal diminati di negara maju serta negara- negara berkembang karena aktivitas obat, tingkat keamanan yang lebih tinggi dan biayanya yang terjangkau, salah satunya adalah semangka dan manggis, pada umumnya buah semangka dan manggis hanya dikonsumsi daging buahnya sedangkan kulit semangka maupun manggis hanya dibuang sebagai limbah tanpa ada pemanfaatan lebih lanjut. Kulit semangka (Citrullus lanatus (Thunb.)) mempunyai kandungan sitrulin yang termasuk tipe golongan alkaloid yang berperan dalam proses penyembuhan luka karena pengaruhnya terhadap angiogenesis, inflamasi, proliferasi sel, deposisi matriks dan remodeling (Niwanggalih. P et al., 2014). Kulit manggis (Garcinia mangostana L.) memiliki kandungan flavonoid berupa xanton yang memiliki efek anti inflamasi dengan memicu pembentukan kolagen yang berperan penting dalam pemeliharaan struktur dan penyembuhan luka (Suratman et al., 1996).

Maka berdasarkan jurnal yang didapatkan sebelumnya dengan kandungan kulit semangka (Niwanggalih. P et al., 2014) dan kulit manggis (Suratman et al., 1996) masing masing dapat digunakan untuk penutupan luka bakar melalui jurnal tersebut apabila dikombinasikan apakah akan dihasilkan khasiat yang lebih baik dalam penyembuhan luka bakar. 
Pengaruh gel kombinasi ekstrak kulit semangka dan kulit manggis terhadap penyembuhan luka bakar belum pernah dilakukan sebelumnya, jika dibandingkan dengan penelitian terdahulu kulit semangka diekstraksi dengan menggunakan alat freeze dryer dengan suhu $32{ }^{0} \mathrm{C}$ tanpa etanol sebagai pelarutnya. Penggunaan ekstrak etanolik diharapkan dapat melarutkan phenolic compound seperti flavonoid dan tanin (Chew et al., 2011). Selain itu, tidak dilakukan kontrol kualitas formulasi sediaan obat dari ekstrak kulit semangka tersebut, melainkan sebatas meneliti jumlah neutrofil pada radang luka gores (Niwanggalih et al., 2014).

Informasi tersebut mendorong peneliti untuk melakukan penelitian dengan merancang suatu sediaan topikal berbentuk gel dengan kombinasi ekstrak kulit semangka dan kulit manggis yang berkhasiat sebagai penyembuhan luka bakar dibuat dalam satu sediaan akan mempermudah dalam pengaplikasian pada kulit.

\section{Metodologi Penelitian}

\subsection{Alat dan bahan}

Peralatan yang digunakan ialah batang pengaduk, blender, cawan porselin, erlenmeyer, $\mathrm{pH}$ meter, viskometer, stopwatch, alat uji daya lekat, kaca, anak timbang, kertas saring, gelas ukur, pot gel, rotary evaporator, t, timbangan analitik, timbangan hewan, sarung tangan, masker, oven, pisau, aluminium foil, kertas saring, kamera, pinset,, water bath.

Bahan uji yang digunakan adalah air suling, , etanol 70\%, serbuk Mg, HCL pekat, HCL $2 \mathrm{M}$, serbuk $\mathrm{NaCl}$, asam sulfat pekat, $\mathrm{NaOH}$, paraffin, reagen wagner, reagen mayer, reagen dragendroff, ekstrak kulit manggis, CMC Na, gliserin, nipagin, gel bioplacenton, ekstrak kulit semangka dan alkohol.

Hewan uji yang digunakan adalah kelinci dengan berat 1,0 - $2 \mathrm{~kg}$ dengan kondisi fisiologis dalam keadaan sehat. Hewan di bagi secara acak ke 7 kelompok perlakuan.

\subsection{Jalannya penelitian}

Kulit buah yang telah dipisahkan dicuci bersih, dirajang tipis-tipis, dikeringkan dengan oven pada suhu $50^{\circ} \mathrm{C}$. Kulit dihaluskan menggunakan blender dan ditimbang 250 gram simplisia kulit semangka dan 100 gram simplisia kulit manggis. Serbuk yang sudah jadi digunakan untuk ekstraksi.

Ekstrak etanol kulit semangka dan kulit manggis dibuat dengan metode maserasi. Serbuk kulit buah semangka direndam dengan 1 liter etanol 70\% dalam bejana maserasi selama $1 \times 24$ jam, sambil sesekali diaduk dan terlindung dari cahaya matahari. Maserat yang telah jadi disaring menggunakan corong, kemudian dipekatkan menggunakan rotary evaporator dan 
selanjutnya diuapkan diatas penangas air. Filtrat yang telah dipekatkan dengan rotary evaporator hingga diperoleh ekstrak kental kulit semangka dan kulit manggis dengan masing-masing rendemen $47,44 \% \mathrm{~b} / \mathrm{b}$ dan $17,6 \% \mathrm{~b} / \mathrm{b}$.

\subsection{Penapisan fitokimia}

\subsubsection{Uji flavonoid}

Ekstrak kulit manggis ditambahkan serbuk Mg dan asam klorida pekat. Apabila terbentuk warna orange, merah atau kuning berarti positif flavonoid.

\subsubsection{Uji alkaloid}

Ekstrak kulit semangka dimasukkan ke dalam gelas beker, ditambah dengan $\mathrm{HCl} 2 \mathrm{M}$ sambil diaduk. Masukkan kedalalam 3 tabung reaksi ditambahkan pereaksi Wagner (+) coklat kemerahan, pereaksi dragendroff $(+)$ orange dan pereaksi mayer $(+)$ endapan putih berarti ekstrak mengandung alkaloid.

\subsection{Penyiapan hewan uji dan pembuatan luka (Ethical Clearance)}

Hewan uji yang digunakan dalam penelitian ini ialah kelinci sebanyak 7 ekor dengan berat 1,0 - $2 \mathrm{~kg}$ dengan kondisi fisiologis dalam keadaan sehat. Hewan di bagi secara acak ke 7 kelompok perlakuan. Setiap kelinci dibuat luka bakar menggunakan lempeng logam panas berdiameter $2 \mathrm{~cm}$.

Mengenai ethical clearance untuk perlakuan terhadap hewan uji pada dasarnya harus ada ethical clearance namun pada praktikum yang dilakukan tidak menggunakan ethical clearance karena laboratorium farmakologi yang ada di STIKES belum mewajibkan adanya ethical clearance.

\subsection{Pengamatan atau pengumpulan data}

Sebelum perlakuan, ditentukan kelinci dengan cara pengacakan. Setelah kelinci dibuat luka, kemudian diukur luas luka awal sebelum dilakukan perlakuan. Masing-masing kelinci diberi perlakuan sebagai berikut perlakuan A (basis), perlakuan B (Bioplacenton ${ }^{\mathrm{TM}}$ ), perlakuan C (KS 100), perlakuan D (KM 100), perlakuan E (KSKM 25:75), perlakuan F (KSKM 50:50), perlakuan G (KSKM 75:25). Dilakukan pengamatan selama 14 hari untuk melihat diameter penutup luka dengan cara mengoleskan secara merata pada daerah luka dua kali sehari. Pengamatan pada luka dilakukan dengan cara mengukur diameter luka. 


\subsection{Evaluasi sediaan gel}

\subsubsection{Uji organoleptik}

Dilakukan secara visual mulai dari tekstur, warna, bau dan rasa dari gel.

\subsection{2. $\mathrm{pH}$}

Masukkan alat $\mathrm{pH}$ meter yang sudah dikalibrasi kedalam gel.

\subsubsection{Homogenitas}

Gel dioleskan pada kaca transparan dimana sediaan diambil 3 bagian yaitu atas, tengah dan bawah. Homogenitas ditunjukkan dengan tidak adanya butiran kasar.

\subsubsection{Daya sebar}

Sebanyak 0,5 g gel diletakkan ditengah kaca. Ditimbang dulu peneutup kaca kemudian diletakkan diatas massa sediaan gel selama 1 menit. Diukur diameter sediaan yang menyebar dengan mengambil rata-rata diameter dari beberapa sisi.

\subsubsection{Daya proteksi}

Kertas saring $(10 \mathrm{~cm} \times 10 \mathrm{~cm})$ dibasahi larutan PP sebagai indikator dan dikeringkan. Olesi dengan sediaan pada kertasa saring. Celupkan kertas saring lain $(2,5 \mathrm{~cm}$ x $2,5 \mathrm{~cm})$ pada bagian pinggir dengan paraffin cair dan setelah kering akan didapat area yang dibatasi dengan paraffin. Kertas saring yang diolesi gel ditempelkan dibawah kertas saring yang diberi pembatas. Area tersebut dibasahi dengan larutan $\mathrm{NaOH}(0,1 \mathrm{~N})$. Dilakukan pengamatan timbulnya warna merah ungu.

\subsubsection{Daya lekat}

Gel 0,5 g diletakkan diatas obyek glass yang telah ditentukan luasnya kemudian diletakkan obyek glass yang lain diatas gel tersebut, ditekan dengan beban 500 g selama 5 menit. Dilepaskan beban $80 \mathrm{~g}$ pada ujung alat dan catat waktu yang diperoleh.

\subsection{Perhitungan data}

Pengukuran rata-rata diameter luka terbuka dilakukan yaitu diameter luka terbuka setiap ulangan perlakuan. Dihitung dengan rumus : $d x=\frac{d x(1)+d x(2)+d x(3)+d(4)}{4} \quad$ untuk rata-rata diameter luka terbuka $(\mathrm{cm})$. Kemudian dilanjutkan dengan perhitungan persentase penyembuhan luka dihitung dengan rumus: $\mathrm{P} \%=\frac{d o-d x}{d o} \times 100 \%$ 
Hasil perhitungan lalu digunakan untuk mengetahui perbedaan panjang luka terhadap setiap perlakuan yang ditunjukkan pada grafik yang dibandingkan dengan kontrol positifnya.

\section{Hasil dan Pembahasan}

Hasil penapisan fitokimia menunjukkan bahwa ekstrak kulit semangka dan ekstrak kulit manggis mengandung alkaloid dan flavonoid. Penapisan ini dilakukan untuk mengetahui berbagai macam kandungan kimia yang terdapat di dalam tumbuhan.

Penggunaan basis Na-CMC dalam pmebuatan gel bertujuan untuk mendapatkan gel yang jernih, bersifat netral dan memiliki daya pengikat yang kuat. Pada pembuatan gel ditambahkan gliserin sebagai humektan yang berfungsi meningkatkan kelembutan, daya sebar serta melindungi dari kemungkinan sediaan menjadi kering.

\subsection{Hasil Pengujian Stabilitas Fisik Gel}

Uji organoleptis warna secara visual menunjukkan bahwa semua formula tidak mengalami perubahan warna selama 28 hari penyimpanan, yakni warna bening (F1), coklat kekuningan (F2), coklat kehitaman (F3), coklat kekuningan (F4), coklat (F5), coklat kehitaman (F6).

Uji homogenitas pada enam formula yan dibuat menunjukkan susunan yang homogen dengan tidak terlihatnya butiran kasar baik pada suhu ruang.

Uji $\mathrm{pH}$ sediaan yang dihasilkan memenuhi rentang $\mathrm{pH}$ kulit 4,0-7,0. Jika $\mathrm{pH}$ yang terlalu asam dapat menyebabkan iritasi kulit dan terlalu basa menyebabkan kulit bersisik.

Uji viskositas menunjukkan semakin tinggi konsentrasi ekstrak maka viskositas sediaan semakin meningkat. Peningkatan jumlah ekstrak dapat memperkuat matriks penyusun gel sehingga mengakibatkan kenaikan. Berdasarkan hasil pengukuran viskositas keenam sediaan mengalami penurunan viskositas hingga hari ke 28.

Uji daya sebar semakin tinggi daya penyebaran sediaan gel maka semakin baik sediaan gel dalam melepaskan zat aktifnya. Daya sebar berkaitan dengan viskositas dan daya lekat sediaan gel. Formula 2 dan 6 memiliki daya sebar yang lebih baik dibandingkan formula lain.

Uji daya lekat untuk mengetahui kemampuan gel melekat pada kulit. Semakin lama waktu gel untuk melekat, semakin besar pula daya lekatnya pada kulit. Formula 3 mempunyai daya lekat paling baik dari enam formula yang diuji.

Uji daya proteksi untuk kriteria gel yang baik yaitu semakin lama penyimpanan maka daya proteksi semakin turun. Pada enam formula yang disimpan selama 28 hari didapatkan hasil mengalami penurunan daya proteksi. 
Uji aseptabilitas untuk mengetahui kualitas gel dan pandangan masyarakat terhadap gel yang dibuat. Uji ini dilakukan pada 20 responden dan didapatkan hasil pada enam perlakuan bahwa sediaan gel dapat diterima oleh responden.

\subsection{Hasil Pengujian Luka Bakar}

Penelitian ini bertujuan untuk mengetahui pada formula berapa gel kombinasi ekstrak kulit semangka dan ekstrak kulit manggis dapat menyembuhkan luka bakar. Pada penelitian ini digunakan ekstrak kulit semangka dan kulit manggis dengan 5 variasi konsentrasi sebagai perawatan luka bakar. Pengamatan perubahan diameter luka bakar dapat dilihat pada gambar 7 .

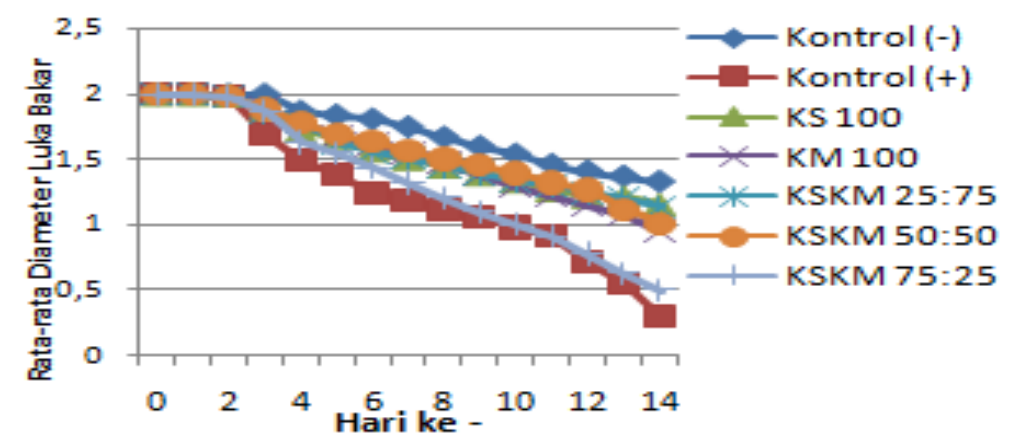

Gambar 1. Grafik rata-rata diameter luka bakar. F1: formula basis, F2: formula gel ekstrak kulit semangka, F3: formula gel ekstrak kulit manggis, F4: formula gel kombinasi kulit semangka dan kulit manggis (25:75), F5 : formula gel kombinasi kulit semangka dan kulit manggis (50:50), F6 : formula gel kombinasi kulit semangka dan kulit manggis $(75: 25)$

Pada gambar tersebut dapat dilihat bahwa dari 7 perlakuan yang diberikan pada masingmasing hewan uji memberikan pengaruh pada diameter luka bakar yang dioleskan 2 kali sehari. Perlakuan pada kontrol negatif menunjukan diameter luka bakar yang paling lebar. Hal ini menunjukkan bahwa luka bakar yang hanya diberi basis memberikan efek penyembuhan yang lebih lama dibandingkan luka bakar yang diberi perlakuan ekstrak dan bioplacenton. Pada perlakuan yang diberi ekstrak menunjukkan hasil yang berbeda pada setiap variasi konsentrasi baik pada bentuk tunggal maupun kombinasinya. Pada formula 6 didapatkan hasil diameter penutupan luka bakar yang mendekati kontrol positif yaitu 1,29 cm. Hal ini menunjukkan bahwa kombinasi kulit semangka $75 \%$ dengan kulit manggis $25 \%$ menghasilkan efek penutupan luka bakar yang lebih baik dibanding kombinasi formula lainnya.

Pengaruh yang ditunjukkan oleh kulit semangka dan kulit manggis dikarenakan adanya senyawa metabolit sekunder. Senyawa gamma mangostin dalam esktrak kulit manggis memiliki khasiat sebagai anti-inflamasi dengan penghambatan COX-2 sehingga mempercepat proses penyembuhan luka pada fase inflamasi. Selain pada fase inflamasi, ekstrak kulit manggis berperan dalam menyembuhkan luka bakar pada fase proliferasi dimana ekstrak kulit manggis 
dapat meningkatkan proses epitelisasi dan mempercepat proliferasi fibroblas (Lutfiyah et al., 2016). Kulit semangka mempunyai kandungan alkaloid berupa sitrulin yang berperan dalam proses penyembuhan luka. Komponen sitrulin dalam jumlah banyak dapat diubah menjadi arginin dalam tubuh. Arginin telah menunjukkan dapat membantu penyembuhan luka dan deposit kolagen pada luka dengan mempengaruhi kecepatan pembentukan kolagen pada daerah luka (Niwanggalih., 2014).
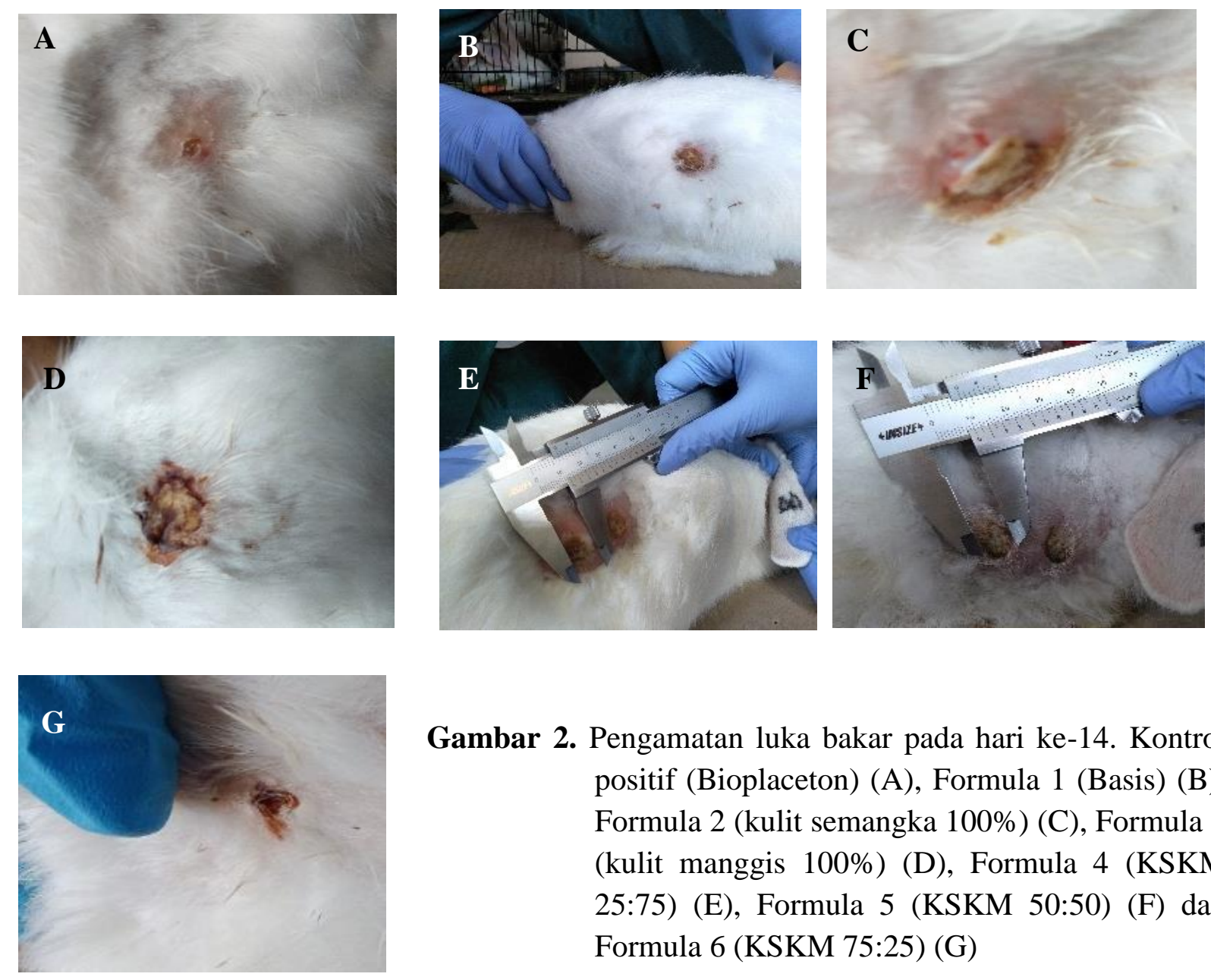

Gambar 2. Pengamatan luka bakar pada hari ke-14. Kontrol positif (Bioplaceton) (A), Formula 1 (Basis) (B), Formula 2 (kulit semangka 100\%) (C), Formula 3 (kulit manggis 100\%) (D), Formula 4 (KSKM 25:75) (E), Formula 5 (KSKM 50:50) (F) dan Formula 6 (KSKM 75:25) (G)

\section{Kesimpulan}

Pemberian gel kombinasi kulit semangka dan kulit manggis pada kelinci dapat memberikan pengaruh terhadap diameter penutupan luka bakar. Formula yang paling efektif dalam penyembuhan luka bakar kelinci adalah formula 3 dengan kombinasi kulit semangka 75\% dan kulit maggis $25 \%$. Sediaan gel kombinasi ekstrak kulit semangka dan kulit manggis terhadap penyembuhan luka bakar pada kelinci memberikan kontrol kualitas yang baik. 


\section{Ucapan Terimakasih}

Kemenristek Dikti Melalui Simbelmawa Atas Program Kreativitas Mahasiswa Penelitian Eksakta Tahun Pelaksanaan 2018.

\section{Daftar Pustaka}

Asri, D. P., 2012, Efektivitas Ekstrak Kulit Manggis (Garcinia mangostana L.) Terhadap Percepatan Proliferasi Fibroblas pada Proses Penyembuhan Luka Traumatik Akut Mukosa Mulut Tikus Wistar, Skripsi, Fakultas Kedokteran Gigi Universitas Airlangga, Surabaya.

Departemen Kesehatan RI, 1979, Farmakope Indonesis Edisi III, Depkes RI, Jakarta

Depkes RI, 2009, Farmakope Herbal Indonesia, Departemen Kesehatan Republik Indonesia, Jakarta

Desiana, Dyah Tantri. 2015. Efek Diuresis Ekstrak Semangka Kuning Berbiji (Citrullus Lanatus) pada Tikus Putih Jantan (Rattus Norvegicus). Karya Tulis Ilmiah strata satu, Universitas Sebelas Maret, Surakarta.

Lutfiyah et al., 2016. Pengaruh Ekstrak Kulit Manggis (Garcinia mangostana L.)

Terhadap Jumlah Neutrofil Pada Inflamasi Pulpa. Fakultas Kedokteran Universitas Lambung Mangkurat Banjarmasin. Jurnal Kedokteran Gigi Vol I. No 2.

Maulana, Lena., Sugihartini, Nining., 2015. Formulasi Gel Ekstrak Etanol Kulit Buah Manggis (Garcinia Mangostana L.) Dengan Variasi Gelling Agent Sebagai Sediaan Luka Bakar. Fakultas Farmasi Universitas Ahmad Dahlan Yogyakarta. Pharmaciana Vol.5. No.1,43-52.

Nisa, Olga N.L, dkk., 2017, Uji Stabilitas Pada Gel Ekstrak Daun Pisang (Gelek Usang), Fakultas Ilmu Kesehatan Universitas Muhammadiyah Magelang. University Research Colloquium.

Niwanggalih, P., 2014. Pengaruh Ekstrak Kulit Semangka (Citrullus Lanatus (Thunb.)) Terhadap Jumlah Neutrofil Pada Radang Luka Gores Mencit (Mus musculus) Jantan BALB/c Dan Pemanfaatannya Sebagai Karya Ilmiah Populer. Karya Tulis Ilmiah Strata Satu, Universitas Negeri Jember, Jember.

Rimando, Agnes M. dan Penelope M. Perkins-Veazie. 2005. Determineof Citrulline in Watermelon Rind. Journal of Chromatography A :196-200. USA

Rizka Ulfatin Arifah, S. N. Nurul Makiyah, 2014. The Potential of Watermelon (Citrullus lanatus) Ethanol Extract as an Anti-Inflammatory through duodenum epithelium Thickness Observation of Mice BALB /c, Karya Tulis Ilmiah, UMY.

Sativa, Oryza, et al., 2014, Uji Aktivitas Antiinflamasi Gel Ekstrak Buah Kaktus (Opuntia elatior Mill.) Pada Tikus (Rattus norvegicus L.) Yang Diinduksi Lamda Karagenan, Fakultas Farmasi Universitas Tadulako. Jurnal of Natural Science Vol.3.No.2,79-94.

Suratman, Sumiwi, S.A., dan Gozali, A.D., 1996, Pengaruh Ekstrak Antanan dalam Bentuk Sediaan Salep, Krim, Jelly terhadap Penyembuhan Luka Bakar, CDK, 108: 31-38

Voight R., 1994, Buku Pelajaran Tekhnologi Farmasi, Gajah Mada University Press, Yogyakarta. 